\title{
SOME CONSIDERATIONS IN THE LAW OF DOMICIL
}

\section{Frederic R. COUderT}

The law of domicil is a subject which, to the everyday practitioner, presents some terror. This is not due to the fact that the legal rules relating to the nature and ascertainment of domicil are more complex, obscure or difficult of application than those relating to other legal subjects, but rather because domicil is a matter which does not very frequently come to the attention of the average lawyer. It, therefore, appears to be involved in that mystery which always enshrouds the unknown, and the mystery is, consciously or unconsciously, enhanced by the Latinized phraseology in which the few adepts have involved the subject.

Domicil has recently met with the fullest discussion in the American Law Institute. It has been the subject of a complete report ${ }^{1}$ by Professor Joseph $\mathrm{H}$. Beale, of Harvard, the great master on the subject of the Conflict of Laws; and his Committee of Advisers to the Institute, and has been fully canvassed in public session. To endeavor, therefore, to discuss the matter de novo or to attempt upon any large scale a criticism of this admirable work would savor strongly of that temerity and valor which can be founded upon ignorance alone.

I make no pretense to any part of that vast erudition possessed by Professor Beale and many of his learned advisers on the subject of the Conflict of Laws. They have examined with minute circumspection all the English and American precedents bearing upon the question of domicil and jurisdiction and have summarized those precedents in carefully drawn propositions which are intended to embody the whole of the common law learning and precedent upon the subject. I can, therefore, only speak as one of the average practitioners who from time to time has been forced to wrestle with questions of the Conflict of Laws, both as between the states of the Union and as between a state and some foreign nation. I shall, therefore, confine my discussion mainly to some of the practical problems that have confronted me and the manner in which they have been dealt with by the courts of New York.

As Professor Beale well says:?

"Domicil is a subject of importance in our law because a con-

1 (1925) The Adierican LaW INSTitute, Conflict of Latis RestateIIENT No. $1, \S \S 10-42$.

2 Ibid. Treatise No. 1 , at 3. 
siderable number of jural relations are determined by the law of the domicil of the person concerned."

This is, indeed, true, since the law envisages every individual at birth as having a domicil. Domicil regulates the most important affairs of his life-the validity of divorce, the legitimncy of children, the imposition of taxes, and the devolution of personal property, whether by will or through intestacy. For this reason, confusion and vagueness in the rules of law may lead to financial loss, family unhappiness and various social ills.

As the world through modern methods of communication grows smaller and as men are more easily shifting their homes, the practical difficulties surrounding the matter dealt with become greater and call more and more for as much legal precision in ascertaining domicil as may be possible.

Underlying the whole law of domicil is, of course, the conception of the necessity for a single law to determine relationships. Status, capacity, the validity of wills, if differently determined in regard to the same person by all the nations of the world, or even by the forty-eight states of the Union, would lead to a condition of complete legal anarchy.

After the break-up of the Roman Empire, under whose rule the world had been almost a legal unit, jurists sought for some method of polarizing law, or of finding some Pole Star by which to determine what rules should govern the individual as to his property or status.

In the so-called Dark Ages each individual

"was subject to the law of the particular ethnic group to which he belonged, and all his proprietary rights were determined by that law. But gradually there grew up in the different towns and provinces certain fixed customs and rules affecting all property within the locality, which were known as 'statutes." "s

These statutes came to be distinguished as real statutes or personal statutes, as they dealt with things or with persons, and a body of doctrine was built up designed to determine whether the statutes to be applied in specific cases were real or personal. As to land, the feudal conception of law as strictly territorial remained supreme, but as to succession and movables, there grew up a doctrine of so-called comity by which the succession was determined by the law of the country or place where the decedent had his last domicil. Before the eighteenth century, with the rise of the great national states, the conception of domicil as the Pole Star for the determination of questions relating to personal property was generally prevalent in Europe. Since then, however, and especially during the nineteenth century

3 Bentwich, Domicile AND Succession (1911) 1-2. 
Western Europe, domicil as the criterion has been replaced by nationality, and upon it the States of Europe, such as France, Italy and Germany, base their international private law. The nationality of a person is deemed to follow him as regards all the major concerns of life-the validity of his marriage, his capacity to contract, his legitimacy, his divorce and the regulation of his succession, are all matters to be determined by the national law.

In Great Britain and the Dominions, the common law still prevails and domicil is, and must be, as it is in the United States, the criterion, because of the many systems of law which exist under the British flag.

The term "residence" is not synonymous with domicil and wherever it appears in statutes or decisions its meaning must be determined. Much confusion arises in the reading of the cases through the using of residence in a double sense, sometimes as meaning true domicil and at other times as meaning mere residence. In the latter sense, i.c., the general meaning of the word, it indicates any place or dwelling of more or less permanence. It is, in fact, anything more than a place of temporary sojourn. In some statutes, residence is given a definition malking it identical with domicil. In other statutes, staying for a fixed period of time in a place will be construed as a residence. A most frequent use of residence is in connection with the acquisition of jurisdiction, as in cases of attachment. In cases of divorce, the word residence would at common law be synonymous with domicil. In the New York statutes, residence is frequently used where domicil is intended, and also in its own proper sense in matters connected with voting, naturalization, attachment, security for costs, arrest for debt, etc.

Owing to the conflicts arising between the common law criterion of domicil and that of the civil law of nationality, there have arisen many interesting and difficult cases. A byr-product of this conflict is the famous doctrine of renvoi. I do not mean here to more than indicate the nature of that troublesome problem. Its discussion has already formed the subject-matter of volumes.

$A$ is an American domiciled in France, leaving property both there and in the state of New York. His succession is opened in New York either by the appointment of an administrator or the probate of a will. The New York law says that devolution of his property, testate or intestate, is determinable by the law of his domicil, and refers the matter to the French law. The French courts hold that it is determinable by the law of his nationality, which is American, and refer the question back to the law of New York, as that of his nationality. The New York court might, of course, refer the matter back to the French law 
after the development and unification of the great nations of and the legal lawn tennis might go on forever. If New York, however, accepted renvoi it would apply its domestic law not as such but because the French law of the domicil so required, an absurd result; in other words, it would decide as the French court would do. In practice, however, the New York court in such a case will apply the French internal or domestic law on the theory that when its statutes referred to the law of domicil they referred to the territorial law there applying to particular situations, and not the rule of international private law for determining questions of conflict. This seems to me to be the sensible view to take and it has finally been sanctioned by the New York courts in the case of In Matter of Tallmadge. ${ }^{4}$

The case was remarkable in that the surrogate acted upon a most scholarly and exhaustive opinion by that late distinguished member of the New York Bar, Mr. Egerton L. Winthrop, Jr. Mr. Winthrop discussed very fully the doctrine of renvoi in its various stages and was aided by experts on foreign law, as well as by the very able counsel. The first question in the case was whether the decedent had a bona fide domicil in France. His parents had lived there for so many years that there was a question whether they had not lost their domicil of origin. He had spent his whole life in France with no evidence of intent to return to the United States and, short of naturalization, could have done little more to establish a permanent home in France. The referee, therefore, very properly determined his domicil to be France.

The important question then arose whether the French law or New York law should apply to certain legacies; by the French law they had lapsed; by the New York law they were valid. The French court would have applied the renvoi doctrine and determined the question by New York law. Was the New York court also to apply that doctrine and decide according to the New York law, or was it to hold that the law to be applied was the internal or territorial law of France which would invalidate the legacies? The referee determined that the latter was the correct view and applied the French law applicable to lapsed legacies.

The New York statute, ${ }^{5}$ which is declaratory of the common law, regulates the disposition of a decedent's property "by the laws of the state or country, of which the decedent was a resident, at the time of his death." This the referee construed to mean the actual territorial law of such foreign state and not the rule which the courts of that state applied to the Conflict of

\footnotetext{
109 Misc. 696, 181 N. Y. Supp. 336 (Surr. 1919). This was the report of a referee, confirmed by the Surrogate's Court.

- Decedent Estate Law, § 47.
} 
Laws. In other words, the New York statute intended to refer to the internal or domestic law of the foreign state and not to the rules or doctrines of international private law propounded by the courts. This opinion is one of the most interesting to be found in the books on any question of Conflict of Laws and it is regrettable that the case did not go to the Court of Appeals. The referee concluded his opinion as follows: ${ }^{\circ}$

"There is thus no authority which compels me to apply the 'renvoi' doctrine to the case at bar. The way is unmarked in this state and should be determined in accordance with sound legal principles. On account of its inconsistency with commonlaw theories of the conflict of laws, its fundamental unsoundness and the chaos which would result from its application to the conflicts arising between the laws of the states of this country, it is my opinion that the 'renvoi' has no place in our jurisprudence."

I have little doubt that the reasoning of this admirable opinion represents the law of New York, and that when the question is presented to the Court of Appeals it will be resolved in precisely the same fashion. The renvoi doctrine is a resultant of legal casuistry and over-subtlety. It is a doctrine over-complicated, unsound and revolutionary.

The whole renvoi doctrine has been admirably discussed by an English practitioner, MIr. Pawley Bate, in an exhaustive monograph. ${ }^{7} \mathrm{He}$ concludes as did the court in the Tallmadge case. Norman Bentwich, however, takes a different view and strongly advocates renvoi, although he admits that it is still a matter of great controversy. He gives an excellent statement of it as follows: ${ }^{8}$

"For example, if today an Englishman dies domiciled by English law in Italy, and leaves personal property in Italy which is not disposed of by any will, an English court having jurisdiction over the estate will first of all have to consider the law which is to be applied to the distribution of the personalty, and will choose the Italian law. But it will have to take account of the fact that the Italian law contains a rule by which the personal property of a foreign resident is distributable according to the law of his nationality, and therefore it has to determine whether that principle of the Italian law is to be applied, or the English rule as to the personal law to be treated as dominant. ... In order to surmount the difficulty caused by the existence of varying principles of private national law in England and Continental countries our Courts [English courts] have tended to accept the reference back to our internal law made by the law of the foreign domicile."

6109 Misc. at 715,181 N. Y. Supp. at 348.

7 Bate, Notes on the Doctrine of Renvor (1904).

8 BENTWICH, op. cit. supra note 3 , at 30 . 
It may be said that the system which is based upon domicil is freer, more elastic and more compatible with the ideas and traditions of the English-speaking people than that which is based upon nationality. One may with reasonable ease change one's domicil. A change of nationality is a much more difficult, serious and important thing.

Those nations which insist upon nationality thereby assert the power of the national state to control all legal relationships of the individual wherever he goes. It is not my purpose here to speak further of the Conflict of Laws in Europe. As between the civil law states there has grown up a large body of treaty law covering private relationships. This has served to mitigate many of the difficulties by giving full judicial recognition in one nation to the judicial acts, decrees or sentences of another. Neither England nor America having been a party to any such treaties, the common law remains unmodified by treaty provisions.

Domicil has been defined in various ways but I quite agree with Professor Beale that the underlying concept of domicil is that of home. Where one has one's fixed home or habitat, there is one's domicil. This is the ordinary case of the normal individual and leads to little difficulty. The difficulties arise where the home is uncertain or in the case of compelled or constructive domicil, that is, in according a domicil to persons who either have no home or, because of their legally incompetent condition, are unable to choose one.

Domicil may well be said to be the place with which a person has a settled connection for legal purposes; either because his home is there or because it is assigned to him by law.

There are several definitions and criteria of domicil, mainly taken from the English cases, which have been adopted by New York law. One of the most interesting and far-reaching discussions of the law of domicil is to be found in the case of Dupuy v. Wurtz. ${ }^{\circ}$ The question there arose over the validity of a will of personal property made by a testatrix, originally domiciled in New York, who went abroad in 1859 on account of her health, and remained abroad until her death in 1871. The opinion was written by Judge Rapallo, a jurist of wide repute, great learning and legal acumen. He laid down the elementary rule for the ascertainment of domicil: ${ }^{10}$

"One leading rule is that for the purposes of succession every person must have a domicil somewhere, and can have but one domicil, and that the domicil of origin is presumed to continue until a new one is acquired. . . .

"To effect a change of domicil for the purpose of succession

${ }^{9} 53$ N. Y. 556 (1853).

10 Ibid. 561 . 
there must be not only a change of residence, but an intention to abandon the former domicil, and acquire another as the sole domicil. There must be both residence in the alleged adopted domicil and intention to adopt such place of residence as the sole domicil."”

The court admitted that the question was one of considerable difficulty and particularly stressed the fact that she was abroad for her health and had no desire to adopt another system of law:

"The present is one of the exceptional cases in which the duty devolves upon this court to pass upon the facts as vell as the law. And we think that the conclusion of fact, fairly to be drawn from all the evidence, is that the testatrix, after having long and consistently entertained the intention of returning, had finally become satisfied. that the state of her health and nerves was such that she would, be unable to return to her home, and would, in all piobability, die abroad. At the same time it establishes no intention to adopt a foreign domicil, but that she desired and claimed to retain her domicil of origin, and to have her estate administered according to the laws of the State of New York." "11 [Our italics].

This latter consideration bulks large in the New York law. I incline to believe that it is inconsistent with some of the views entertained by the Committee of the American Law Institute. As I understand the report made to that body, it expressly negatives the idea that a party may choose his domicil, using domicil as a legal concept-once having established his home somewhere, the law automatically designates that "somewhere" as his domicil. He chooses his home but the law alone determines his domicil. Is it, then, possible for a party, who does in fact have his home abroad but indicates unequivocally by his formal declarations that he is domiciled in New York, thus to succeed in having his property and succession governed by the New York laws? ${ }^{2}$ The Dupuy case seems to me to go very far in the direction of allowing it.

The view propounded to the Institute is that the intcat, which is one of the two necessary constituents to creatc domicil, is not the intent to have a legal domicil but the intent to have a home. The domicil is created by law, not by intent of the party, although it is admitted that a man may take up his home where he chooses for any reason which he may think desirable, such as divorce, avoiding taxation, or otherwise. It is strongly argued that he cannot actually live in one locality for his own comfort and convenience and maintain, for instance, a wholly political

\footnotetext{
11 Ibid. 565.

12 See also Hegeman v. Fox, 31 Barb. 475 (N. Y. Sup. Ct. 1860) ; Hislop จ. Taaffe. 141 App. Div. 40, 125 N. Y. Supp. 614 (2d Dept. 1910); Jones r. St. John, 30 Can. 122 (1899).
} 
residence in a place where he does not really desire to live, although it is admitted that if he has two homes he may choose one of them as his principal establishment. I incline to think that there is in this a disposition to endeavor to reduce the law of domicil to too rigid and systematic a formulation, and that in so doing we may not make the law any more certain. There is a strong tendency in the courts of New York, as of England, to refuse to hold a man domiciled abroad when he has evinced his intention of retaining his American or English domicil of origin despite the fact that his real home is abroad.

I do not think that the New York cases can be fitted completely into the home theory of Professor Beale much as I like its simplicity and clarity. While the existence of a home is an important evidentiary element in the ascertaining of a domicil, I cannot agree with Professor Beale that as to the New York law, at least, it is conclusive. In the Dupuy case the home was clearly not in New York and yet the testatrix was held domiciled there because of her intent not to abandon hed domicil there.13 Nor is this case an obsolete one. It is still, I think, the leading case on the law of domicil in New York.

Counsel for the contestants in that case insisted that the law would not permit the testatrix by mere intent to retain her domicil of origin in defiance of the facts. "Recitals of domicile in a deed or will and declarations thereof are not conclusive and may be rebutted by proof that the actual domicile [home] was elsewhere." This contention was negatived by the Court of Appeals and it is the doctrine so negatived which appears to have been adopted by the American Law Institute.

I think it quite true that a person cannot change his domicil by removal to a new dwelling place without intention to make the new dwelling place his home, but this statement does not meet the really difficult situation. That situation arises where a party does intend to make the new dwelling place his home, but does not intend to abandon his domicil of origin which, because of sentimental or practical considerations, he formally intends to retain.

A most interesting and leading case upon this point is Matter of Newcomb. ${ }^{14}$ Mrs. Newcomb had long lived in New York, as well as in New Jersey and elsewhere. After she was some eighty years of age she began spending considerable time in New Orleans, where she was interested because she had founded there a memorial monument for her daughter. It is evident that she anticipated a contest over her will, in which

13 The question of intention to retain a domicil as contra-distinguished from a home appears to be a predominant consideration in the case of De Meli v. De Meli, 120 N. Y. 485, 24 N. E. 996 (1890).

14192 N. Y. 238, 84 H. E. 950 (1908). 
the question of domicil would play an important rôle. In 1898, knowing that she had declared herself a resident of New Jersey in civil documents and acting under advice of counsel, she executed several formal declarations, in one of which she said: ${ }^{1 s}$

"I have now concluded to make my permanent home here, because on each succeeding day of my life now drawing to a close, I am the grateful witness of the successful development and steady growth of this noble institution [referring to the Memorial College], which now engrosses my thoughts and purposes and is endeared to me by such hallowed associations. In order that there may be no occasion for misappiehension hereafter, especially in any matter touching the settlement of my estate, I desire to have it known by my particular fricnds that I have elected to make the city of Ncw Orleans my place of domicile and permanent home, although of course I may occasionally visit or reside in other places."

It appears that during the four years preceding this declaration she spent upwards of 500 days in New Orleans, as compared with less than 150 in New York City. Between the date of the declaration and the date of her death she spent less than 200 days in New Orleans and more than 600 in New York City, dividing the rest of the time between summer resorts in New York State, where she had once admittedly been dormiciled, and New England. The court held that such declarations were admissible as evidentiary of the intent of the testatrix as to domicil. The necessity for a single domicil as contra-distinguished from a mere residence was clearly set forth in the admirable opinion by Judge Vann: ${ }^{16}$

"As domicile and residence are usually in the same place, they are frequently used, even in our statutes, as if they had the same meaning, but they are not identical terms, for a person may have two places of residence, as in the city and country, but only one domicile. Residence means living in a particular locality, but domicile means living in that locality with intent to make it a fixed and permanent home. Residence simply requires bodily presence as an inhabitant in a given place, while domicile requires bodily presence in that place and also an intention to make it one's domicile. ...

"Residence is necessary, for there can be no domicile without it, and important as evidence, for it bears strongly upon intention, but not controlling, for unless combined with intention it cannot effect a change of domicile."

It will be noted that in this case and throughout the cases generally, domicil is often used in the sense of "home" and not in the strictly technical sense as a term indicating a legal rela-

\footnotetext{
15 Ibid. 247,84 N. E. at 953 .
}

${ }^{16}$ Ibid. 250,84 N. E. at 954 . 
tionship. The court emphasizes the fact that the whole question is one of fact rather than of law, and that a person may effect a change of domicil for any reason whatever: ${ }^{17}$

"A change of domicile may be made through caprice, whim or fancy, for business, health or pleasure, to secure a change of climate, or a change of laws, or for any reason whatever, provided there is an absolute and fixed intention to abandon one and acquire another and the acts of the person affected confirm the intention. . . . No pretense or deception can be practiced, for the intention must be honest, the action genuine and the evidence to establish both, clear and convincing. The animus manendi must be actual with no animo revertendi."

It was permissible, therefore, for Mrs. Newcomb to make the change, ${ }^{18}$

"because she preferred the people, the climate or the laws of Louisiana to those of New York, or even because she wished to have her will proved and her estate settled there. She could accomplish nothing by merely pretending to change her domicile, while really intending to retain it in New York. If she had made the most formal declaration of intention for the purpose of creating evidence of an apparent change, with no intention of making an actual change, it would have been a fraud and of no effect."

While the opinion thus clearly formulated the general rule that one cannot have a domicil without a real as distinguished from a colorable home it is, nevertheless, probable that without Mrs. Newcomb's declaration electing domicil in New Orlenns, the courts would have concluded that she was domiciled in New York or New Jersey. Aside from her actual residence in New York during the greater part of her life she expressed a wish "to die in New York and be buried in Greenwood Cemetery." I incline to believe that while, as the court says, it would be impossible for a person to create a domicil without any basis of residence by mere statements alone, nevertheless, a very limited residence, especially if it be in the state or country of origin, is necessary in a case where one having another residence elects to consider his domicil at the first residence.

It is a settled doctrine of the Conflict of Laws that a person may elect, there being nothing in the law and public policy of the forum to the contrary, to have his succession governed by the rules of another system of law. This is called "voluntary submission" or "autonomy of the will." It is recognized in the state of New York by statute: ${ }^{10}$

17 Ibid. 251,84 N. E. at 954.

18 Ibid. 252, 84 N. E. at 955.

${ }^{19}$ N. Y. Decedent Estate Law, § 47. 
". . Whenever a decedent, being a citizen of the United States ... wherever resident, shall have declared in his will and testament that he elects that such testamentary dispositions shall be construed and regulated by the laws of this state, the validity and effect of such disposition shall be determined by such laws."

The very purpose of this statute was to enable New York citizens long resident abroad to put a clause in their wills which might obviate the necessity for protracted litigation over the domiciliary question. As a matter of fact, I may say that the law was suggested, prepared and pressed through the legislature by a former very prominent judge of the Court of Appeals who was concerned over the situation not infrequently arising regarding non-domiciled residents of New York who left property in New York State. While the New York courts have been careful, in phrase at least, to adhere to the general principles of the common law as laid down in England and as followed generally in the United States as to domicil, they have gone very far in sustaining a New York domicil where the testator had declared his domicil there, even though the basis for his residence was indeed slim.

As is well said in a note in the YALE LAW JOURNAL, commenting upon a recent case of domicil: :0

"The advantage of a fixed rule for the acquisition of a domicil of choice is that it gives a definite standard to the courts for a large majority of cases. But the certainty is limited, and the fixed rule has serious disadvantages. In cases with unusual facts, it forces the court either to make decisions which are socially undesirable, or in an effort to avoid such decisions, while still doing lip-service to the fixed rule, to strain and distort the rule in order to reach a sound result."

The Supreme Court in Massachusetts, in 1840, had the candor to declare ${ }^{21}$ that "no exact definition can be given of domicil; it depends on no one fact or combination of circumstances, but from the whole taken together it must be determined in each particular case." This somewhat vague and pragmatic view, while it may sound philosophical, appears to give little comfort to the practitioner who is searching for some fixed criteria in order that he may intelligently advise his client. It is defended, however, by an acute and scholarly author, Professor W. W. Cook, of Yale, on the following ground: :?

20 (1927) 36 Yate LaW JourNaL, 408, 412.

21 Thorndike v. Boston, 1 Metc. 242, 245 (IIass. 1840).

22 Cook; The Logical and Legal Bases of the Conflict of Laws (1924) of YALE LAW JouRNaL, 457, 487. 
"This view does not lead to the discarding of all principles and rules, but quite the contrary. It demands them as tools with which to work; as tools without which we cannot work effectively. It does, however, make sure that they are used as tools and are not perverted to an apparently mechanical use. It points out that the use never can be really mechanical; that the danger in continuing to deceive ourselves into believing that we are merely 'applying' the old rule or principle to 'a new case' by purely deductive reasoning lies in the fact that as the real thought-process is thus obscured, we fail to realize that our choice is really being guided by considerations of social and economic policy or ethics, and so fail to take into consideration all the relevant facts of life required for a wise decision."

I am inclined to think that this gives a pretty fair picture of the judicial mental process in many of these domicil cases and accords pretty well with the admirable analysis of that process furnished us by Judge Cardozo: ${ }^{23}$

"Deep below consciousness are other forces, the likes and the dislikes, the predilections and the prejudices, the complex of instincts and emotions and habits and convictions, which make the man, whether he be litigant or judge. .... I do not doubt the grandeur of the conception which lifts them into the realm of pure reason, above and beyond the sweep of perturbing and deflecting forces. None the less, if there is anything of reality in my analysis of the judicial process, they do not stand aloof on these chill and distant heights; and we shall not help the cause of truth by acting and speaking as if they do."

An interesting case may be found in a careful opinion by the late Surrogate Thomas. ${ }^{24}$ It involved the question of the domicil of one Spencer who, having a New York domicil of origin, had been brought up in France and lived there the greater part of his life. His social and intellectual interests were all in France or Italy but he nevertheless adhered to his Americanism and spoke and thought of himself as an American citizen domiciled in New York. Despite the evidence of his preference for living abroad, the surrogate held that he was domiciled in New York. While he had described himself as a resident of France in an affidavit made to avoid taxation, the learned surrogate distinguished between such residence and domicil, saying:

"The declarations of the decedent as to his residence being in New York, made on registering in hotels, in legal writings, in applications for passports and in other memoranda, with the single exception of this one tax affidavit, agree in claiming residence in New York."

${ }^{23}$ Cardozo, The Nature of the Judicial Process (1921) 167-8.

24 Matter of Spencer, N. Y. L. J. June 2, 1908 (not reported). 
Referring to his arrest in France the opinion says:

"He never ceased thereafter to speak harshly on all permissible occasions of the French government and people, and nothing in the whole history of the incident would justify an inference that he ever entertained the slightest uish to submit his estate and affairs to French law as a person haring his domicil in France." [Italics ours].

It is clear that the judgment in this case was based upon the evident intent of the testator to retain not so much a home in New York as his American citizenship with all that it connoted. In other words, he was one of those who wished to live abroad but to retain all the rights, privileges and immunities belonging to the law of his domicil of origin.

A recent and exceedingly notable instance of this very natural judicial attitude in favor of domicil of origin, an attitude which the practicing lawyer in advising his client must have in mind, is found in the case of United States Trust Co. of New York 2 . Hait. ${ }^{25}$ Here the testator was born in 1836 in Virginia, removed with parents to New York in 1859, where he lived until 1880, in the meantime making frequent trips abroad. From 1880, after he had retired from business, he spent most of his time in Paris, where he had a luxurious home. He returned for short trips to America, the last trip having been made in 1904, his death occurring in 1912. In 1881 he married in London, but in 1883 he procured a judgment of divorce in New York. Prior to 1892 he adopted and brought up in his household in France a young child who was one of the defendants in the action. He adopted her according to the statutes of New York. While living in Paris he became a member of the American colony, and purchased a burial plot in the American cemetery, in which he was subsequently buried. $\mathrm{He}$, however, kept his property in $\mathrm{New}$ York, his will was in the English language, and in documents generally he described himself as of New York. He never renounced his citizenship nor took any steps to become a citizen of France. He had no physical residence in New York, save so far as membership in a club might be so considered. His interests, aside from financial, were wholly in France and one of the parties making claims in regard to his succession was a lady who had long occupied a prouxorial position in his household.

It would indeed seem very clear upon the facts in this case that Hart had but one home and that home was in Paris. In New York he had nothing in the physical and material sense of the word that would be considered a home, at least for a man of his position and manner of living. He was an American and

25150 App. Div. 413, 135 N. Y. Supp. 81 (1912) ; affd without substantial modification, 208 N. Y. 617, 102 N. E. 1115 (1913). 
retained his citizenship; he desired to have his property governed by the New York law and he lept his investments in the city of New York. He spent his time in France in which he maintained an establishment with every regular or other incident which might be connected with a permanent home. It is, indeed, going far to say, as we must if we follow the general principles as laid down in the law of domicil, that he had two homes and that he merely, by his volition, elected which one he desired to have considered as his domicil.

This is not a case of a man having a country and a city home and electing to treat the one as the home and the other as a residence. In such event, both residences have at all times the characteristics of home; he but leaves one temporarily, intending to return to it, and lives in a precisely similar fashion in the second as he lived in the first home. Throughout the year his thoughts may turn to either residence as his home, yet he must be regarded as still actually at home in both residences as distinguished from legally domiciled in both. I do not see how this principle could be fairly determinative of the Hart case where there was no factual foundation upon which to predicate the existence of two homes. The Appellate Division found, however, that his retention of citizenship and of his investments in New York, together with his continuous declarations that he was domiciled in New York were inconsistent with an intention to change his domicil from New York to Paris.

It is thus clear that the New York courts, in common with the English courts, require more evidence in order to find a man has changed his domicil of origin than is necessary for the changing of a domicil of choice. It has been stated that the American cases do not treat domicil of origin differently from domicil of choice. This may well be true of some of the cases throughout the United States cited to sustain this proposition, but I challenge it so far as New York is concerned. The New York cases have cited the English cases on this point and have, I think, strictly followed their doctrine.

In the Hart case the opinion of the court, in sustaining the New York domicil, marshals the various declarations of the decedent throughout his sojourn in Paris, in all of which he declares himself as of New York, and concludes as follows: ${ }^{20}$

"It would serve no useful purpose to review at length here
the evidence offered as to his oral declarations or declarations
written to friends as to his interest in the United States and its
affairs, or statements to his friends in Paris as to his enjoying
Parisian life and his love for its laws in preference to those of
the United States, and that he intended to always live there.
The fact is that in every formal act of his life, so far as
appears, where it became necessary for him to state his dom-

${ }^{26}$ Ibid. 418,135 N. Y. Supp. at 85. 
icil, he invariably claimed it as the State of New Iork and not France. [Our italics].

"Unless one's domicil can be changed for him, without his intention, or in spite of his intention, he must be considered, at the time of his death, as domiciled in the State of New York."

While there can be no doubt whatever that Hart never intended to change his domicil, it seems to me equally clear that he did actually change his home. If I am right in this, the general principles usually laid down by the American courts do not really solve a problem of this hind. Where a person, after having had an unquestioned domicil in New York, later actually: establishes his home abroad but continues to have business relations with New York and claims New York as his domicil in all formal documents, the precedents clearly indicate that New Yorl: courts will consider him as still domiciled in the state of New York. Although the New York courts, like the English courts, have repudiated the confounding of domicil with nationality, they continue to be very reluctant to deny to an undoubted American citizen the privilege of being governed by his own law and will seize upon the most exiguous evidence of colorable residence in order to effect his formal intent to retain a domicil in New York. The Hart case, which was bitterly contested and very completely argued through to the Court of Appeals, seems admirably to illustrate this judicial attitude.

An attempt was made in 1863 by Lord Cranworth in the House of Lords ${ }^{2 z}$ to formulate this theory. According to the doctrine as propounded by him, a domicil of choice is not acquired by any residence, however preponderant and however permanent, unless the person in question has the intention of subjecting himself and his movable succession to the law of that country, or at least, if he does not think expressly of the law, he has the intention of so incorporating himself with the population of that country that the application of its law to him and to his movable succession must be considered to be in accordance with his feelings. This doctrine was termed by Lord Cranworth as "the modern, improved view of domicil."

This dictum of Lord Cranworth has given rise to much discussion both in the courts and among legal witers in England. Some of Cranworth's expressions, such as quatenus in illo evere patriom have been entirely repudiated. Lord Westbury, in the famous case of $U d n y v$. $U d n y$, ,s distinguished between the political status "by virtue of which each individual becomes the subject of some particular country binding him by the tie of national allegiance" and the civil status "by virtue of which he

27 Moorhouse v. Lord, 10 H. L. Cas. 272 (1S63).

$2 s$ (1869) L. R. 1 H. L. [Sc.] 441. 
is possessed of certain municipal rights subject to certain obligations." Since that time, the distinction between the civil status dependent upon domicil and the public status of allegiance dependent upon nationality has been maintained by the English courts.

The present result of the English cases, according to Westlake, is as follows: ${ }^{29}$

"The animus required for acquiring a domicile of choice must be an intention, either formed by the de cujus or which it may be believed that he would have formed if his thoughts had been crystalised by a question put to him, to reside in the fullest and most permanent way, and in that sense to acquire a new domicile, but it need not be an intention to subject himself to another system of law, or to identify himself with the social ideas and habits of another country."

A case which is very much in accord with the line of reasoning followed in the New York cases referred to is that of Winans $v$. Attorney General. ${ }^{30}$ Winans, although of American origin, had had his home in England for a great many years and the lower courts had held him domiciled there, but this decision was reversed on appeal on the ground that: ${ }^{31}$

"What has here to be considered ... is whether the testator . . . ever actually declared a final and deliberate intention of settling in England, or whether his conduct and declarations lead to the belief that he would have declared such an intention if the necessity of making the election between the countries had arisen." "

While there was no mention of the question of political allegiance or reference to Lord Cranworth's dictum, it seems to me that the doctrine of the Winans case was fundamentally like that of Moorhouse v. Lord ${ }^{32}$ to the effect that a change of domicil could not be effected as against the wishes and declarations of a person who desired to retain his domicil of origin.

I incline to think that the disposition shown by the court in Moorhouse $v$. Lord is one that will always actuate our courts when a similar situation arises. ${ }^{33}$ Such a situation can not be governed by a nice balancing for the purpose of discovering which of two real homes a testator elected to treat as his domicil, but if a testator who has one actual home has maintained any

29 Westlake, Private International LaW (5th ed. 1912) 362.

30 [1904] A. C. 287.

31 [1904] A. C. 287, 292.

32 Supra note 27.

33 See McDonald v. Hartford Trust Co., 104 Conn. 169, 132 Atl. 902 (1926). 
semblance of a residence in the state of his origin and nationality, even though it be merely a right of membership in a club, the court will hold him domiciled here, if such has been his intention. In other words, certain sentimental considerations which have not yet been to my mind adequately, and perhaps can not be completely adequately formulated, will be the preponderant factor in the minds of the judges. This perhaps subconscious judicial process will prevent the denationalization of an American who, however much he enjoys being at home in Europe, desires that his sentimental, business and legal connection with his native land remain intact. 